\title{
Thi" 离 THE MOLLUSCA COLLECTION OF THE UNIVERSITY OF SÃO PAULO MUSEUM OF ZOOLOGY: AN OVERVIEW AND PERSPECTIVES
}

\author{
A Coleção de Moluscos do Museu de Zoologia da \\ Universidade de São Paulo: visão geral e perspectivas
}

Daniel C. Cavallari'; Luiz R. L. Simone ${ }^{2}$, Sérgio M. de Almeida ${ }^{3}$, Natan C. Pedro ${ }^{4}$, Cibele A. Carvalho ${ }^{4}$

\begin{abstract}
The Mollusca Collection of the University of São Paulo Museum of Zoology is a century-old assemblage, possibly one of the largest in Latin America, reaching a total of 123,000 lots and over 1.2 million specimens. Its coverage in terms of geography and biodiversity encompasses the entire Brazilian territory and over 130 countries, and its specimens are the starting point for important studies in the field of Malacology. In this study, numbers, curatorial aspects and the Collection's role in education, research and outreach are addressed. Challenges and future prospects are also presented and discussed.
\end{abstract}

Keywords: Assemblage, Biodiversity, Curatorial methods, Natural History, Taxonomy.

\section{RESUMO}

A Coleção de Mollusca do Museu de Zoologia da Universidade de São Paulo é um acervo centenário que pode ser descrito como um dos maiores da América Latina, chegando a um total de 123 mil lotes e mais de 1.2 milhão de espécimes. Sua representatividade em termos de biodiversidade e cobertura territorial abrange todo o território nacional e mais de 130 países, e seu acervo é ponto de partida para importantes estudos na área da Malacologia. No presente trabalho, números, aspectos curatoriais e o papel para o ensino, pesquisa e extensão da Coleção são abordados. Desafios e perspectivas futuras são também apresentados e discutidos.

Palavras-chave: Acervo, Biodiversidade, Curadoria, História Natural, Taxonomia.

\footnotetext{
${ }^{1}$ Museu de Zoologia da Universidade de São Paulo (MZUSP), Av. Nazaré, 481, Ipiranga - CEP: 04263-000 São Paulo, SP. E-mail: dccavallari@usp.br

2 Professor Livre-Docente (MZUSP). E-mail: Irsimone@usp.br

${ }^{3}$ Professor Assistente, Universidade Católica de Pernambuco, Rua do Príncipe, 526 - CEP: 50050-900. Recife, PE. E-mail: smalmeidasj@ gmail.com

${ }^{4}$ Bolsista DTI-C CNPq (MZUSP). E-mails: natan_pedro@yahoo.com.br, cibelecarvalho22@yahoo.com.br
} 


\section{INTRODUCTION}

The Mollusca Collection of the University of São Paulo Museum of Zoology (MZUSP) is one of the most important collections of its kind in Latin America, and possibly the largest. Erected by the accumulated efforts of several researchers for over a century, the collection currently houses more than 123,000 lots and 1.2 million mollusk specimens from different regions of the world. Encompassing freshwater, terrestrial and particularly marine environments, the collection includes bivalves, gastropods, cephalopods and other less diverse mollusk groups, preserved dry (shells, fossils) or in fluid (specimens with soft parts).

The collection began as one of the several assemblages that belonged to the Museu Paulista by the end of the 19th century. Its oldest items date from the mid-1880s, part of the personal study material of the German-Brazilian researcher Hermann von Ihering, who also became its first curator. With the subsequent formalization of the Museum of Zoology as an independent institution with its own center of operations in the 1940s, the collection received its private room, where it remains since then (Abreu, 2000). Several private collections were subsequently incorporated into it, such as the collections of Jorge Vaz, Francisco L. Morretes, De Fiore, Marcus \& Marcus, Hemmen (Wiesbaden), Femorale, among others (see Cavallari \& Simone, 2015; Cavallari et al., 2016).

The relevance of MZUSP's collection for the development of studies on mollusks in Brazil and
Latin America is recognized and often recollected (Simone, 2003; Colley et al., 2012). Several renowned researchers worked directly or indirectly with the assemblage since its creation, and the study of its specimens has brought and still brings forth articles, monographs and theses, both nationally and abroad (e.g., Leme, 1973; Simone, 2004; Dornellas \& Simone, 2011; Simone, 2011). In order to highlight the collection's representativeness and taxonomic importance at national and international levels, a descriptive study is herein presented, and curatorial aspects and future prospects are discussed.

\section{MATERIAL \& METHODS}

\section{Curatorial methods}

The Mollusca Collection is arranged in its own grounds of $190 \mathrm{~m}^{2}$ in MZUSP dependencies, sharing its space with the associated laboratory where studies and curatorial procedures are carried out. The items in the collection are arranged in three large sliding cabinets (Figure 1A) that allow for sufficient brightness input control. The cabinets contain mainly steel drawers (Figure 1B) with electrostatic powder coating. Specimens are organized in phylogenetic order and enclosed in lots, each consisting of a vial containing individuals of the same species collected at the same location during the same event or sampling effort (same date, same collectors). The number of specimens varies from one to up to $\sim 5000$, to an approximate average of 10 specimens per lot. Lots preserved in fluid ( $35 \%)$, such as ethanol, formalin or other solutions, are stored in soda lime

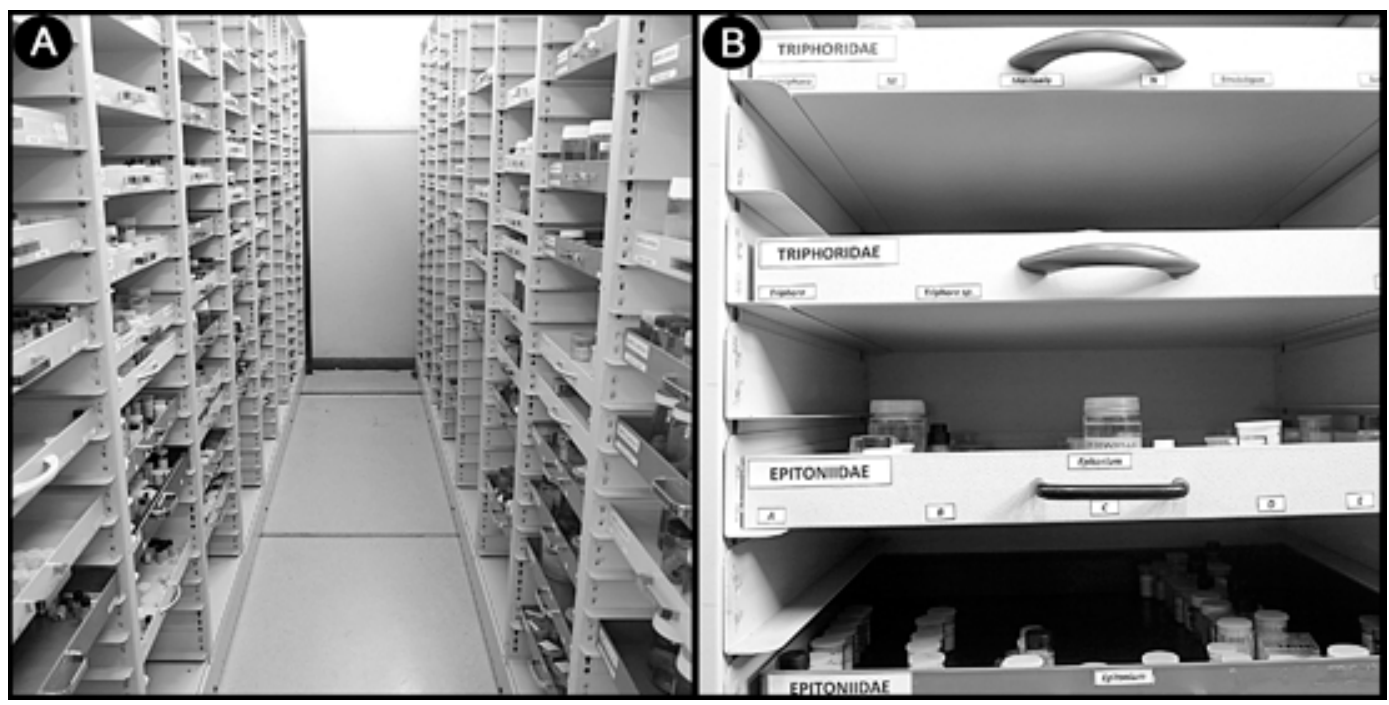

Figure 1 - Physical structure of MZUSP's Mollusk Collection. A) Corridor between two sliding cabinet modules; B) Steel, powder-coated drawer, with lots organized by families, genera and species. 
glass, borosilicate glass or polyethylene (PET) vials with proper sealing. Dry-preserved lots $(\sim 65 \%)$ are stored in polypropylene (PP) or acrylic bottles. Each lot recently incorporated into the collection receives an individual, sequential and permanent catalog number. Constituent specimens may be empty shells, fossils or any body parts (dry snail eggs, pens, and beaks of cephalopods, for example) that do not require preservative fluid (dry), or soft tissue with or without shells (when applicable), preserved in fluid. The main preservative fluid used in the collection is ethanol diluted $70-80 \%$, but a small number of specimens are preserved in formaldehyde, RaillietHenry solution, Bouin, and creosote, among others.

Wood, cork, and other non-treated cellulose derivatives, which are mostly heritage of older parts of the assemblage, have been continuously removed from the collection and replaced. This is necessary considering the physical and chemical damage that these materials can cause to calcareous specimens by the release of volatile acids, a phenomenon known as Bynesian decay or "Byne's disease" (Shelton, 1996; Sturm, 2006; Cavallari et al., 2014). Aimed at obtaining a completely archival setting, buffered, chemically treated, resistant paper (Resistall ${ }^{\mathrm{TM}}$ ) has been progressively employed for label printing. With the same purpose, the printing itself is only done with carbon-based ink. Humidity and temperature are currently controlled by air conditioners in continuous use $\left(24^{\circ} \mathrm{C}\right)$. Such measures are also useful to control other pests that can affect natural history collections, such as dust, insects and mold (Sturm, 2006).

In addition to field samplings conducted by the MZUSP, the collection receives specimens originating from research projects in the country and abroad, through prior arrangement with the head curator. These samples are generally obtained through donations and exchanges and are mainly destined to serve as a testimony of studies (vouchers) or taxonomical identification. By means of agreements with institutions abroad, the collection also receives materials from other collections around the globe, for example, Muséum national d'histoire naturelle (France), American Museum of Natural History, Academy of Natural Sciences of Drexel University and California Academy of Sciences (USA), Australian Museum (Australia), Zoologische Staatssammlung München (Germany), Naturalis Biodiversity Center (Netherlands), among many others. These materials are intended for study and are housed temporarily in an especially reserved area before returning to their source. The collection currently has a significant number of type specimens deposited by the Malacology Lab team, other local research groups and researchers around the world. Altogether, there are 1120 specimens among primary (263) and secondary (857) types.

\section{RESULTS}

\section{Coverage and diversity}

The more than 123,000 lots in the collection harbor an impressive amount of mollusk specimens from over 130 countries, but most of the assemblage contains representatives of the Neotropical fauna, with emphasis on Brazilian and South American specimens. Of the total number of lots, about $74 \%$ are from Brazil, $4 \%$ from the rest of South America and $4 \%$ from Central America and the Caribbean. North America, Asia, Europe and Africa each has 2\% of the lots, and the remaining items are divided between Antarctica and Indo-Pacific (Figure 2). Nearly $7 \%$ of the lots contain uncertain or doubtful locality data; usually, these are older items.

The regional coverage of Brazilian lots is distributed as follows (Figure 3): 61\% originated

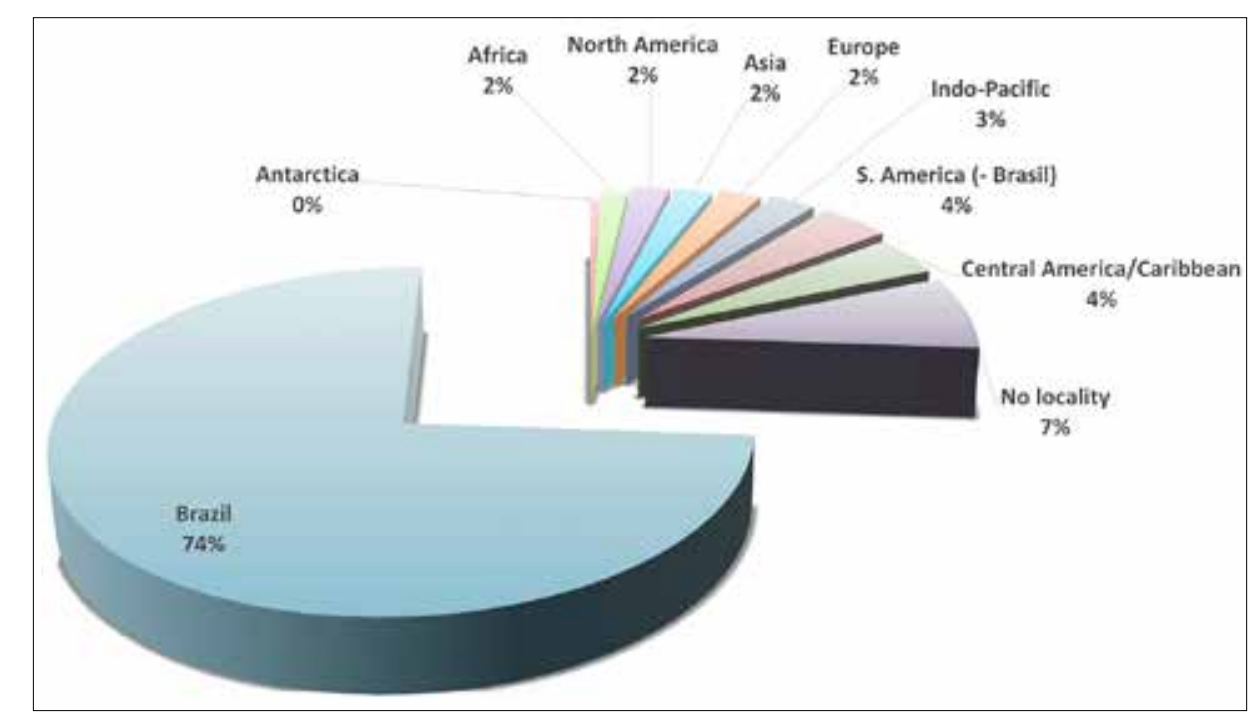

Figure 2 - Percentage of MZUSP's Mollusca Collection lots coming from each continent. 
from the Southeast; $22 \%$ from the Northeast; $8 \%$ South, 1\% North, 1\% from the Midwest. Approximately $7 \%$ of the Brazilian lots have no precise locality. Among the states (Figure 4), São Paulo is the one with the largest number of lots $(40 \%)$, followed by Rio de Janeiro (13\%). The remaining states account for less than $50 \%$ of the lots, the most representative being Bahia (9\%), Espírito Santo (6\%), Paraná (5\%) and Pernambuco $(3 \%)$. The states of Acre, Roraima, Tocantins, Rondônia and Amazonas together add up to 598 lots (less than $0.5 \%$ of the total).

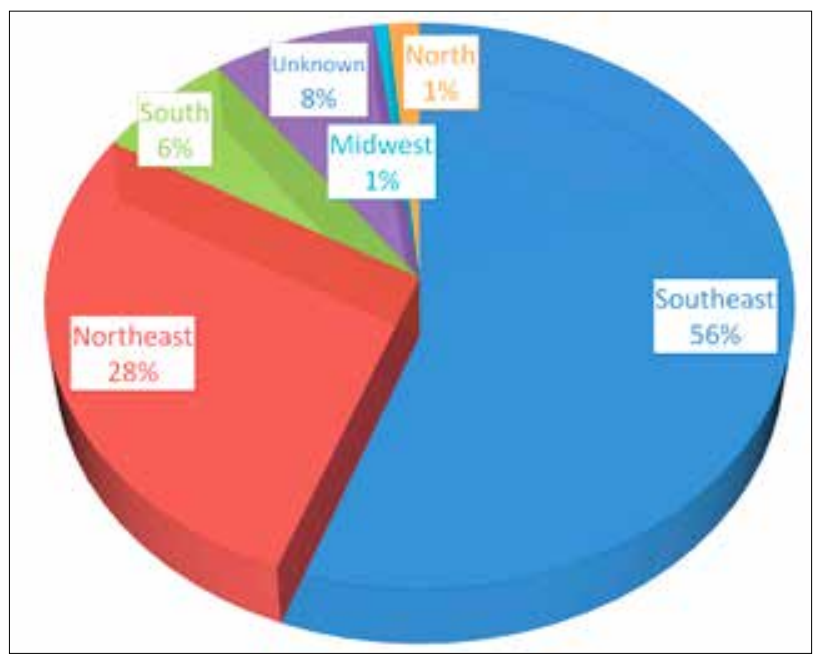

Figure 3 - Percentage of Brazilian lots of MZUSP's Mollusca Collection coming from each of the country's administrative regions.

In terms of diversity within the phylum, about $68 \%$ of the lots belong to the class Gastropoda, ca. $28 \%$ to Bivalvia and the remainder $(4 \%)$ encompasses other classes, including Aplacophora, Cephalopoda, Polyplacophora, and Scaphopoda. About 500 mollusk families are represented in the collection. The most abundant among the bivalves are Veneridae (5321 lots), Arcidae (2434), Tellinidae (2316), Mytilidae (1847), Cardiidae (1205) and Ostreidae (1151). Among the gastropods, the most numerous are Muricidae (5191), Bulimulidae (3329), Olividae (2719), Turridae (2442), Strophocheilidae (2353) and Trochidae (2199). In the other classes, the most abundant families are Ischnochitonidae (Polyplacophora, 1261 lots), Dentaliidae (Scaphopoda, 759), Loliginidae (Cephalopoda, 311) and Chaetodermatidae (Aplacophora, 114).

\section{Education, research, and outreach}

Since its creation, the collection was the foundation for the development of several studies. Among those formally linked to the institution, there were 15 undergraduate monographs, 14 master's theses, 8 doctoral theses, and 7 post-doctoral projects. There are also several ongoing studies, including a master's thesis and 6 doctoral theses with terms set between 2016 and 2018. Numerous research projects have also found their foundations in the collection. In recent years, a project aimed at producing a catalog of the South American marine mollusk fauna (FAPESP 2015/13039-8) and another one on the phylogeny of the superfamily Tonnoidea (CNPq 301725/2013-6) are some examples, among many others. Moreover, voucher specimens of important expeditions and projects are deposited in the collection. Such is the case in the material of the French-Brazilian expedition Marion Dufresne MD55 held in the mid-80s (Tavares, 1999), and specimens coming from recent projects

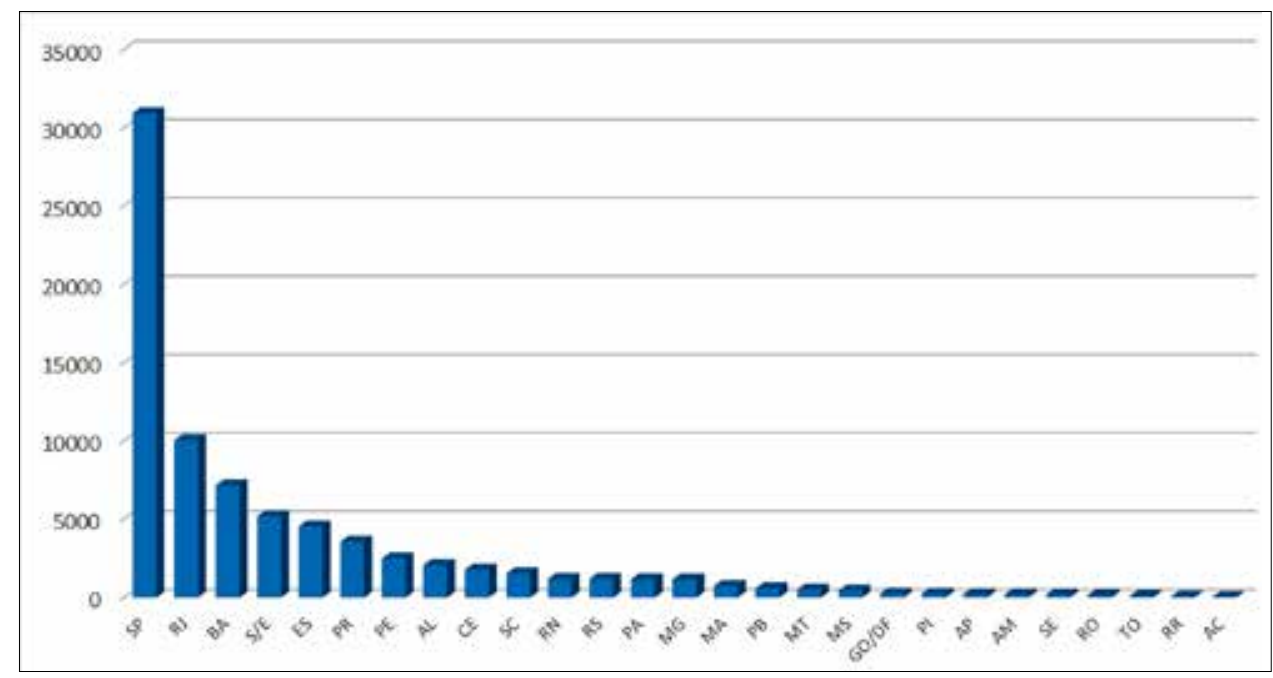

Figure 4 - Number of lots of the MZUSP's Mollusca Collection coming from different Brazilian states. 
such as the survey of the malacofauna of Vitória, Búzios and Alcatrazes Islands (CNPq 475995/2010-4) and Trindade and Martim Vaz Islands (CNPq 557166 / 2009-8).

The Mollusca Collection of MZUSP has also fulfilled its social role in the three pillars of the University of São Paulo: education, research, and outreach. Regarding educational activities, the MZUSP harbors two graduate programs, one of them focused on biodiversity and fully developed by the institution. The Mollusca Laboratory currently has five students from this program and teaches three graduate courses (MZP5018 and BIZ5707 on Malacology and MZP5030 on publications in zoology). MZUSP is also engaged in general biology, teaching several elective courses, one of them developed in Mollusca Laboratory (MZC0012 on Malacology). These activities find indispensable educational support in the collection, which is visited by the students under the supervision of the acting Curator.

In the field of research, MZUSP is proportionally one of the most productive institutions in Brazil. From the second half of the 20th century to this day, authors directly linked to the institution have published hundreds of articles taking into account its collections, with more than 30 major research projects funded by federal and state agencies. Regarding outreach, a number of popular courses are taught at the museum, based on a modern and interactive public exhibit. The collection is an important part of these activities because some of its items are exposed to the public. Most of these items reflect new discoveries by the local research team and are thus aimed at demonstrating the wondrous world of mollusks and promoting the fascination with Malacology.

\section{DISCUSSION AND PERSPECTIVES}

Although there are notable gaps in the collection' territorial coverage, the establishment of new partnerships has sought to fill them. In Brazil, a few states are underrepresented, such as those of the North and Midwest regions, which together account for less than $2 \%$ of the total number of lots in the collection. Still, thanks to the efforts of researchers from various state and federal institutions, the collection has received an increasing number of donations of specimens originated from these localities and this problem tends to be gradually solved.

The collection currently has $100 \%$ of its lots registered in electronic platforms such as MS Excel ${ }^{\circledR}$ and SOPHIA Acervo®. Nonetheless, with the help of a project organized by the Sistema de Informação sobre a Biodiversidade Brasileira (SIBBr) of the Brazilian Federal Government (CNPq 380590/2016-6, CNPq $380518 / 2016-3)$, the Specify 6 platform is being implemented. Data input is currently at $40 \%$. This project has a dedicated team (DTI-C CNPq grants), which develops optimization and data input activities. The use of the Specify 6 platform will enable the online availability of the collection, including information on each lot and highresolution images of type specimens. Finally, it will allow for the integration of the collection into a national biodiversity information network and other databanks such as the Global Biodiversity Information Facility (GBIF).

From a curatorial point of view, the collection has had many structural improvements over the last ten years. The removal of lignin and cellulose-based materials, particularly wood and non-treated paper, and their subsequent replacement for safer archival materials such as powder-coated steel and buffered paper have substantially reduced the cases of deterioration in the collection. Ideally, the total elimination of non-archival materials must be reached, but with the increasing shortening of resources for research and development in Brazil, this goal is likely to be achieved much more slowly than initially expected.

Deposited in the collection's cabinets are specimens collected in a time when natural environments of the country were much less degraded. Similarly, voucher material of historical studies by renowned researchers populates the many drawers arranged in the collection. The value of these specimens is incalculable and their condition makes them irreplaceable. Moreover, the range of studies currently being developed involving Brazilian mollusk species, partially or totally based on the collection's specimens, further reinforces its importance. Starting point of some of the most relevant studies on mollusks produced in Brazil and the world, the Mollusca Collection of MZUSP is recognized as an assemblage of great national and international relevance. Storing and organizing this huge collection requires a great amount of financial and human resources, which, unfortunately, have been steadily reduced due to the crisis in the national economy and decrease in financial support for basic research in zoology and taxonomy. It is always important to recall the fragility of this type of collection: without proper care, these specimens are at constant risk of being 
lost, and along with them a huge and vital amount of information on the country's biodiversity.

\section{REFERENCES}

Abreu, A.A. Quantos Anos Faz o Brasil? EDUSP, 187 p., São Paulo, 2000.

Cavallari, D.C. \& Simone, L.R.L. Incorporation of the Jorge Vaz Collection into the Museu de Zoologia da Universidade de São Paulo. Strombus, São Paulo, v.22, n.1-2, p.29-36, 2015.

Cavallari, D.C.; Dornellas, A.P.S. \& Simone, L.R.L. Second annotated list of type specimens of molluscs deposited in the Museu de Zoologia da Universidade de São Paulo, Brazil. European Journal of Taxonomy, n.213, p.1-59, 2016.

Cavallari, D.C.; Salvador, R.B. \& Cunha, B.R. Dangers to malacological collections: Bynesian decay and pyrite decay. Collection Forum, v.28, n.1-2, p.35-46, 2014.

Colley, E.; Simone, L.R.L. \& Silva, J.L. Uma viagem pela história da Malacologia. Estudos de Biologia Ambiente e Diversidade, Curitiba, v.34, n.83, p.175190, 2012.

Dornellas, A.P.S. \& Simone, L.R.L. Annotated list of type specimens of mollusks deposited in Museu de
Zoologia da Universidade de São Paulo, Brazil. Arquivos de Zoologia, São Paulo, v.42 n.1, p.1-81, 2011.

Leme, J.L.M. Anatomy and systematics of the Neotropical Strophocheiloidea (Gastropoda, Pulmonata) with the description of a new family. Arquivos de Zoologia, São Paulo, v.23, n5, p.295-357, 1973.

Shelton, S. The shell game: Mollusks shell deterioration in collections and its prevention. The Festivus, v.28, n.7, p.74-80, 1996.

Simone, L.R.L. Histórico da malacologia no Brasil. Revista de Biologia Tropical, v.51, supl.3, p.139147, 2003.

Simone, L.R.L. Morphology and phylogeny of the Cypraeoidea (Mollusca, Caenogastropoda). Papel Virtual, 183 p., Rio de Janeiro, 2004.

Simone, L.R.L. Phylogeny of the Caenogastropoda (Mollusca), based on comparative morphology. Arquivos de Zoologia, São Paulo, v.42, n.2-4, p.161323, 2011.

Sturm, C.F. Archival and curatorial methods, p. 4557, in Sturm, C.F.; Pearce, T.A. \& Valdés, A. (eds.) The Mollusks: A Guide to Their Study, Collection, and Preservation. Universal Publishers, 445 p., Boca Raton, 2006.

Tavares, M. The cruise of the Marion Dufresne off the Brazilian coast: account of the scientific results and list of stations. Zoosystema, Paris, v.21, n.4, p.597-605, 1999. 